\title{
Physical inactivity and associated factors in adults of a basic health unit: An observational cross-sectional study
}

Jéssica Lucio da Silva1', Rodrigo Franco de Oliveira², Larissa Dragonetti Bertin'1, Priscila Daniele de Oliveira', Flavia Beltrão Pires', Ana Flávia Spadaccini', Monique Vieira de Souza ${ }^{3}$, Adriele Flausino dos Santos ${ }^{3}$, Deise Aparecida de Almeida Pires-Oliveira²

\begin{abstract}
Background: Physical inactivity (PI) is one of the most important risk factors that contribute to the development of chronic diseases, including cardiovascular diseases. Objective: To analyze the prevalence and associated factors with $\mathrm{Pl}$ in adults from a Basic Health Unit in the city of Uraí, state of Paraná. Methods: An observational, descriptive, cross-sectional study was performed at Basic Health Unit of Uraí, and 100 subjects of both genders were evaluated, the average age of $47.55 \pm 17.13$ years. The data collection was carried through an interview where information of sociodemographic characteristics, consumption of alcoholic beverages, tobacco use, level of physical activity (PA) (IPAQ-8, short version), information of anthropometric measures, waist circumference, and rest blood pressure were collected. The Chi-square and Odds Ratio test was used, considering $95 \%$ of confidence interval, using the statistical package SPSS, version 20.0, with a significance level of $p<0.05$. Results: The prevalence of PI on the sample studied was $66 \%$ in both genders. The factors significantly associated with the PI were: advanced age $\geq 40$ years $(p<0.01)$, overweight with BMI $\geq 25$ ( $p<0.013$ ), abdominal circumference above $102 \mathrm{~cm}$ in men and $88 \mathrm{~cm}(p<0.042)(P<0.001)$ and high blood pressure $\geq 130 / 85 \mathrm{mmHg}(p<0.025)$. Conclusion: The prevalence of associated factors with PI it is high, which suggests the need of public policies and awareness of the importance of oriented-prevention physical activity practice.
\end{abstract}

Keywords: Motor Activity, Risk Factors, Prevalence.

\section{INTRODUCTION}

Physical activity (PA) has become an important public health issue for developed and developing countries, such as Brazi $^{(1,2)}$, because its regular practice is capable of providing health and well-being benefits, leading to a reduction in mortality rates and minimizing the development of noncommunicable diseases number, such as cardiovascular diseases ${ }^{(3,4,5)}$. The World Health Organization characterizes physical inactivity (PI) as the fourth leading risk factor for mortality worldwide and over the years this mortality rate from $\mathrm{Pl}$ increased from 1.9 million in $2005^{(6)}$ to 3.2 million in $2008^{(7)}$ and 5.3 million in $2012^{(5)}$.

Conformingto Buenoetal. ${ }^{(8)}$ and Ranasingheetal. ${ }^{(9)}$, areduction of the PI can minimize the occurrence of noncommunicable diseases from 6 to $10 \%$ and increase the life expectancy of the world's population by 0,68 years. Thereby, the evidence suggests it in order to reduce the risk of developing cardiovascular diseases, it is necessary for adults to routinely practice at least 150 minutes of moderate to vigorous intensity PA per week ${ }^{(3,10,11)}$. The data showed $20 \%$ of Brazilian adults are not very active (PA only once a week) and only $8 \%$ practice
PA regularly (three times a week). This result justifies the importance of PA programs as a resource for the minimization approach to cardiovascular diseases ${ }^{(12,13)}$. Consequently, promoting PA among adolescents and young adults is a strategy that may help reduce PI levels and the development of associated diseases in future generation ${ }^{(9)}$, demonstrating the lifestyle modification is essential in the therapeutic process and prevention of cardiovascular diseases. The present study sought to analyze the PI prevalence and associated factors in adults of a Basic Health Unit located in Uraí, State of Parana.

\section{METHODS}

The present study consists of an observational, descriptive, cross-sectional population-based on a survey conducted from June to July/2014, whose population base were constituted by the residents of the municipality of Uraí-Paraná. The study protocol was approved by the Ethics committee (CEP) under protocol $\mathrm{N}^{\circ} .774,200$. Data collection was performed through a sociodemographic interview and the evaluation of anthropometric measures such as weight, height, abdominal

CORRESPONDING AUTHOR: Deise A. A. Pires-Oliveira. Centro Universitário de Anápolis, UniEVANGÉLICA. Av. Universitária km 3,5. Cidade Universitária - Anápolis (GO), Brazil. CEP: 75.083-515. E-mail: deisepyres@gmail.com

2 Universidade do Norte do Paraná (UNOPAR), Londrina (PR), Brazil

Full list of author information is available at the end of the article.

Financial Support: None.

Submission date 08 March 2017; Acceptance date 24 August 2017; Publication date 02 April 2018 
circumference (AC) and blood pressure (BP). The sample consisted of 100 subjects, 71 of the female gender and 29 of the male gender, the average age of $47.55 \pm 17.13$ years, who sought the services of a Basic Health Unit (BHU) in this period. Inclusion criteria were: age $\geq 18$ years and consent to participate in the study. The exclusion criteria were: 1) to be submitted to special diets established by nutritionists; 2) pregnant or in the first two months postpartum;3) present some physical limitation that would make impossible the measurement of the anthropometric measurements.

\section{Evaluation protocol}

The data collection instrument was composed of sociodemographic variables (gender, age, marital status, education and socioeconomic status) and cardiovascular risk factors (alcoholism, smoking, sedentary lifestyle, obesity, increased AC and high BP). The interview was conducted individually for each participant, by a single interviewer. In anthropometry were obtained measurements of height, body mass and waist circumference. An aluminum stadiometer with a $1 \mathrm{~mm}$ scale was used for the determination of the measures equivalent to height, while a body weight scale was used, with a precision of $0.1 \mathrm{~kg}$. The subject should be barefoot and wearing only light clothes. The measures of weight and height were used to calculate the body mass index (BMI) by the equation: [body mass $(\mathrm{kg}) /$ height $(\mathrm{m})^{2}$ ], being considered overweight those with a value $\geq 25$. Following the recommendations already validated and described in the literature ${ }^{(13)}$. In the assessment of AC, the procedure described by Andersson et al. ${ }^{(14)}$ was used with the subject in the upright position, with relaxed abdomen, arms at the side of the body, using an inelastic tape measuring up to $150 \mathrm{~cm}$ at the midpoint between the last rib and the iliac crest without compressing the tissues, the measurement being taken during expiration, being measured twice to avoid the calibration bias.

Abdominal obesity was established according to the criteria of the National Cholesterol Education Program (NCEP), determined by the values of $102 \mathrm{~cm}$ for men and $88 \mathrm{~cm}$ for women, described by Taylor et al. ${ }^{(15)}$. BP verification was performed using the calibrated $300 \mathrm{~mm} / \mathrm{Hg}$ mercury column sphygmomanometer and stethoscope. The sphygmomanometer was placed in the upper left arm, above the antecubital space, the subject was in a comfortable position (seated) with forearm supported and performed the measurement after 5 minutes of rest. Three measurements were taken during the interview, at the beginning, middle and at the end, and afterwards the average was obtained between them, being considered with altered BP the subjects who presented Systolic Arterial Pressure and Diastolic Blood Pressure $\geq 130$ / $85 \mathrm{mmHg}$, following the published reference values by Weber et al. ${ }^{(16)}$, and after confirming these altered systolic values, they were invited to return to UBS for side dish. In order to define the socioeconomic level, we used the procedures proposed by the Brazilian Association of Research Companies ${ }^{(17)}$, which estimates the purchasing power of families from highest to lowest purchasing power in classes $A 1, A 2, B 1, B 2, C 1, C 2, D$ and $E$, based on the accumulation of material goods, housing conditions, number of domestic workers and the level of education of the head of the family. Because they presented a small number of subjects in each category, categories $A$ and $B$ were grouped in $A+B$ (high) and $C, D$ and $E$ in $C+D+E(\text { low })^{(18)}$. For the data related to alcohol consumption, tobacco use and eating habits, a structured questionnaire used by Martini(19) was used in his study. The issues inherent in the consumption of alcoholic beverages were analyzed through classification strata: alcoholic; those who consumed $\geq 1$ dose in the last 30 days and not alcohol users. Smoking was classified into two categories: a) smoker, for those who smoked, regardless of frequency and quantity of cigarettes; b) non-smoker.

The volunteers PA level was evaluated through the application of the International Physical Activity Questionnaire (IPAQ), translated and validated for Brazil, which takes into account the activities practiced for at least ten continuous minutes performed in the previous week by reports of frequency, intensity and duration ${ }^{(20)}$, being an easy-to-use instrument in a good stability of measurements and an acceptable accuracy ${ }^{(21)}$. subject were classified as active and insufficiently active, with active subject achieving at least 300 minutes of moderate and vigorous PA or insufficiently active for those who reached less than 300 minutes.

\section{DATA ANALYSIS}

Data analysis appropriated the descriptive method with average and standard deviation. For each risk factor, the frequency of those who presented values above the respective recommendations was calculated. The Chi-square test and Odds Ratio were used, considering a 95\% confidence interval, and significance of $p<0.05$. The chi-square test was used to compare continuous and categorical variables. For these procedures the IBM Statistical Package for the Social Sciences 23.0 (IBM Corp., Armonk, New York) was used.

\section{RESULTS}

The sample consisted 100 subjects of both genders, 71 females and 29 males, the average age of $47.55 \pm 17.13$ years. The sample was composed mainly of subjects aged $\geq 60$ years (27\%), female (71\%), low socioeconomic class $(79 \%),(66 \%)$, non-smokers (90\%), non-use alcohol (82\%) and high BP showed a moderate cardiovascular risk (72\%). (Table 1).

The association between $\mathrm{Pl}$ and the investigated variables is presented in table 2 . It is clear the PI increased significantly with the advancing age, corresponding to $50 \%$ in the subjects $\geq 60$ years $(p<0.001)$, it is higher in the female gender. When compared by schooling, subjects who attended high school, corresponding to $\leq 8$ years of schooling, had a higher 
Table 1. Sociodemographic, anthropometric and lifestyle characteristics.

\begin{tabular}{cccc}
\hline Variables & & N & $\%$ \\
\hline Age range & $18-29$ years & 20 & $20 \%$ \\
& $30-39$ years & 12 & $12 \%$ \\
& $40-49$ years & 25 & $25 \%$ \\
Gender & $50-59$ years & 16 & $16 \%$ \\
Education & $\geq 60$ years & 27 & $27 \%$ \\
& Women & 71 & $71 \%$ \\
Socioeconomic level & Men & 29 & $29 \%$ \\
Nutritional status & $>8$ years of study & 21 & $21 \%$ \\
& $<8$ years of study & 79 & $79 \%$ \\
Abdominal circumference & High & 21 & $21 \%$ \\
Physical Activity Level & Low Medium & 79 & $79 \%$ \\
& Normal & 31 & $31 \%$ \\
Smoking & Overweight & 67 & $67 \%$ \\
& Normal & 44 & $44 \%$ \\
Alcoholism & Accented & 56 & $56 \%$ \\
& Active & 44 & $44 \%$ \\
& Insufficient Active & 66 & $66 \%$ \\
& Non-smoking & 90 & $90 \%$ \\
& Smoker & 10 & $10 \%$ \\
& Abstainers & 82 & $82 \%$ \\
& Current Consumer & 18 & $18 \%$ \\
& Low & 28 & $28 \%$ \\
& Moderate & 72 & $72 \%$ \\
\hline \multirow{2}{*}{ Cardiovascular risk } & & & \\
& & &
\end{tabular}

prevalence of being insufficiently active, corresponding to $53.6 \%$ ( $p<0.001$ ) when compared to those with high schooling. In terms of the socioeconomic level its prevalence was higher in the Low-middle class $(78.6 \%)$ and in the subjects that presented overweight and accentuated AC, 89.3\% ( $p<0.013)$ and $75 \%$ ( $p$ respectively, are insufficiently active. As for the high BP contributes to the moderate cardiovascular risk, it is noted that not achieving the recommendation of PA per week showed a higher prevalence of risk, and a large part of the interviewees were considered inactive presenting a greater chance to develop cardiovascular diseases corresponding to $64.3 \%(p<0.025)$.

subjects with low schooling, overweight, accentuated AC, and altered BP have a higher odds ratio for being insufficiently active. There was a linear association between the age group and the $\mathrm{PI}$, therefore the prevalence of the PI increased as age increased, in relation to schooling, subjects with up to 8 years of schooling considered low $(O R=5.237 \mathrm{Cl}=2.015-13.610)$ is 5 times more likely to be insufficiently active than those with schooling above 8 years of age. Regarding nutritional status, it was observed that overweight subjects with $\mathrm{BMI} \geq 25$ $(O R=5.303: \mathrm{Cl}=1.464-19.24)$ were 5 times more likely to be inactive than those with normal nutritional status. In relation to $\mathrm{AC}(\mathrm{OR}=3.000: \mathrm{Cl}=1.135-7.931)$, subjects with accentuated circumference were 3 times more likely to be insufficiently

Table 2. Association between Physical Inactivity and variables investigated among adults of a Basic Health Unit, Uraí, PR.

\begin{tabular}{|c|c|c|c|c|}
\hline \multirow{2}{*}{ Variables } & & \multicolumn{2}{|c|}{ Physical Inactivity } & \multirow{2}{*}{ OR $\left(\mathrm{IC}_{95 \%}\right)$} \\
\hline & & $n(\%)$ & $\mathbf{P}$ & \\
\hline \multirow[t]{5}{*}{ Age range } & $18-29$ years & $1(3.6)$ & & \\
\hline & $30-39$ years & $3(10.7)$ & & \\
\hline & $40-49$ years & $6(21.4)$ & $0.0001 *$ & \\
\hline & $50-59$ years & $4(14.3)$ & & \\
\hline & $\geq 60$ years & $14(50.0)$ & & \\
\hline \multirow[t]{2}{*}{ Gender } & Female & $18(64.3)$ & 0500 & $1550(0609-3943)$ \\
\hline & Male & $10(35.7)$ & 0.500 & $1.550(0.609-3.943)$ \\
\hline \multirow[t]{2}{*}{ Marital status } & Single & $9(32.1)$ & 0780 & $1267(0-502-2106)$ \\
\hline & Cohabitation & 19 (67.9) & 0.189 & $1 . \angle 6 /(0.50<-3.190)$ \\
\hline \multirow[t]{2}{*}{ Education } & $>8$ years of study & $13(46.4)$ & $0001 *$ & $5-227(2015-126101$ \\
\hline & $\leq 8$ years of study & $15(53.6)$ & $0.001^{*}$ & $5.23 /(2.015-13.610)$ \\
\hline \multirow[t]{2}{*}{ Socioeconomic Level } & High & $6(21.4)$ & 0.836 & $0.965(0.332-2804)$ \\
\hline & Low Medium & $22(78.6)$ & 0.836 & $0.963(0.332-2.804)$ \\
\hline \multirow[t]{2}{*}{ Nutritional status } & Normal & $3(10.7)$ & $0012 *$ & \\
\hline & Overweight & $25(89.3)$ & $0.013^{\circ}$ & $5.303(1.463-19.224)$ \\
\hline \multirow[t]{2}{*}{ Waist Circumference } & Normal & $7(25.0)$ & $0092 *$ & $2000(1135 \quad 7021)$ \\
\hline & Accented & $21(75.0)$ & $0.042^{*}$ & $3.000(1.135-1.931)$ \\
\hline \multirow[t]{2}{*}{ Cardiovascular risk } & Low & $10(35.7)$ & $0025 *$ & $3824(1332-2027)$ \\
\hline & Moderate & $18(64.3)$ & 0.020 & $3.024(1.335-2.037)$ \\
\hline \multirow[t]{2}{*}{ Smoking } & Non-smoking & $25(89.3)$ & 0825 & $1114(0267-4652)$ \\
\hline & Smoker & $3(10.7)$ & 0.825 & $1.114(0.26 /-4.652)$ \\
\hline \multirow[t]{2}{*}{ Alcoholism } & Non-consumerist & 26 (92.9) & 0112 & (260 $10058-1258)$ \\
\hline & Current consumer & $2(7.1)$ & 0.143 & $0.209(0.038-1.238)$ \\
\hline
\end{tabular}

\# Linear Association; * $p<0.05$ 
active than those with normal circumference. Relating to cardiovascular risk $(\mathrm{OR}=3.824 ; \mathrm{Cl}=1.333,2.037)$, the subjects with elevated BP had moderate cardiovascular risk, showing a 3 -fold increase in the risk of being insufficiently active compared to those.

\section{DISCUSSION}

The PI prevalence was $66 \%$ observed in the adult population surveyed in the city of Uraí-PR, it was associated with age, low educational level, nutritional status, AC and cardiovascular risk. This data is in agreement with other studies that also associate with age and low schooling ${ }^{(22-24)}$. The positive association between $\mathrm{PI}$ and obesity was also found in other studies ${ }^{(25-28)}$. Other recognized risk factors for $\mathrm{PI}$, such as smoking and alcoholism, were not associated in the present study. Regarding age, a systematic review conducted in Brazil on the level of PA indicates a large variation of inactive subjects in several age groups (29) and this has been frequently exposed in the literature in which the IF index has been increasing by the increasing of the age.

A study conducted by Zanchetta et al. ${ }^{(24)}$ in an urban population living in the state of São Paulo to analyze the $\mathrm{PI}$ associated with risk factors, the subjects evaluated were 30 years of age or older and with less schooling were significantly inactive consequently more exposed to develop risk factors when compared to subjects under the age of 30 in which they were most active. Souza et al. ${ }^{(23)}$ studied the prevalence of PA associated with risk factors in the adult population of São Paulo, they also showed the PI rises with the advancing age, this can be explained by the fact that from adulthood, a slow metabolic rate occurs, weight moderation becomes more difficult, progressive decrease in joint mobility, resistance, balance and strength muscle, making the active behavior of adults and the elderly limited ${ }^{(30)}$.

In brief, we observed the need for surveillance and PA programs, which assess the needs of adults and the elderly. They are the largest dependents of care in public policy processes. We found an inequality of the $\mathrm{PI}$ according to schooling, since $79 \%$ of the Uraiense population had less than 8 years of schooling, of which $53.6 \%$ were insufficiently active and then became an important factor contributing to the development of cardiovascular diseases. This finding corroborates the results of another study carried out not only in Brazil (10) but also in another country like Finland where they sought to analyze the association of education with $\mathrm{PI}^{(31)}$.

Del Duca et al. ${ }^{(32)}$ conducted a study to analyze how gender and schooling interact in the PI patterns in adults; they found the lowest index of PA is related to the lower level of schooling, in which subjects presented only 5 to 8 years of complete studies. However, Souza et al. ${ }^{(10)}$ have shown in their studies the higher level of schooling, the PI lower. This can be explained by the fact of adults with a better educational level have greater access to knowledge, as well as better material conditions ensuring healthy practices and living habits, since people with less education usually have lower purchasing power and, consequently, less opportunity for the practice of $\mathrm{PA}^{(24)}$.

Overweight and obesity both are the sixth most important risk factor for the development of cardiovascular diseases. A survey by the World Federation of Obesity in 2012 found that about one billion adults worldwide are overweight and 475 million are obese ${ }^{25)}$. We observed $67 \%$ of the general population were overweight, while $56 \%$ presented an increase in AC, when associated with the practice of PA $89.3 \%$ and $75 \%$, respectively, were inactive. Visceral obesity, regardless of age, has been considered a risk factor for the development of incapacitating diseases such as acute myocardial infarction, coronary artery disease, diabetes mellitus and musculoskeletal disorders, contributing to a decrease in functional capacity ${ }^{(26)}$.

Turi et al. ${ }^{(33)}$ verified in their studies the aggregation of abdominal obesity with IF was a significant detrimental factor, in which the inactive subjects showed the highest level of obesity, coming against our findings, since the inactive subjects were overweight. This result can be attributed to the fact that obesity in adults is a result of their childhood and adolescence, since much of the habits and lifestyle obtained in youth which can be transferred to adulthood ${ }^{(30)}$. In this way, this phase of life can be considered as key to interventions and modifications of healthy habits and behaviors, such as regular practice of PA. Another important result of this study was the association of PI with cardiovascular risk. It is known that the development of cardiovascular diseases is significantly associated with sedentarism, in addition, it has been verified in the literature an important relationship between physical exercise intensity and immune response, as evidenced by a lower prevalence of some diseases such as acute myocardial infarction, arterial hypertension, stroke and heart failure in groups of people who were more active ${ }^{(30)}$. This association has been investigated by several researchers over the years to verify its effectiveness in the prevention, reduction or control of diseases.

The study by Vilela et al. ${ }^{(34)}$ found that subjects who practiced regular exercise had a $30 \%$ lower risk of developing arterial hypertension than physically inactive subjects. According to Hegde and Solomon ${ }^{(35)}$ the PI increases the incidence of arterial hypertension by $30 \%$ in relation to the physically active ones. For Oliveira-Campos, Maciel and Neto ${ }^{(18)} \mathrm{Pl}$ is an important risk factor for the occurrence of cardiovascular events and a higher mortality rate in subjects with a low level of physical fitness, in agreement with the results of this present study. Recognizing these diseases as a high risk of morbidity and mortality in the national and global context and as a serious health problem, it is necessary to increase their vigilance and control. Therefore, understanding the risk factors associated with $\mathrm{PH}$ can contribute to the development of effective intervention programs, and it is necessary to develop strategies in public health to disseminate and stimulate adherence to $\mathrm{PH}$ practice so that the population 
begins to develop and maintain the habit of practice regularly, especially at younger ages, so that they remain in adulthood.

\section{CONCLUSION}

To sum up, physical inactivity is an important indicator of several risk factors such as advanced age, low schooling, overweight, accentuated abdominal circumference and high blood pressure and may be related to the incidence of chronic diseases. In conclusion, physical activity is a tool of great importance in health promotion.

\section{AUTHOR'S CONTRIBUTION}

JLS performed the practical part, collected, analyzed the data, wrote and edited the article. RFO, LDB and PDO collaborated with the practical part, collecting the data and assisting in the writing of the methods. FBP and AFS participated in the elaboration of the data analysis. MVS and AFS participated in the discussion. DAAPO participated in the orientation, writing and final revision of the article.

\section{CONFLICTS OF INTEREST}

The authors declare no conflict of interest.

\section{AUTHOR DETAILS}

1 Programa de Pós Graduação Ciencias da Reabilitação, programa associado Universidade Estadual de Londrina (UEL)/Universidade Norte do Paraná (UNOPAR), Londrina (PR), Brazil.

${ }^{3}$ Curso de Fisioterapia, Universidade do Norte do Paraná (UNOPAR), Londrina (PR), Brazil.

\section{REFERENCES}

1- Melo AB, Carvalho EM, Sá FGS, Cordeiro JP, Leopoldo AS, LimaLeopoldo, AP. Nível de atividade física dos estudantes de graduação em educação física da universidade federal do Espírito Santo. J. Phys. Educ. 2016;27(1):1-12.

2- Marques A, Sarmento H, Martins J, Nunes LS. Prevalence of Physical Activity in European Adults - Compliance with the World Health Organization's Physical Activity Guidelines. Prev Med. 2015;81(1):1-19.

3- Moniruzzaman M, Ahmed MA, Zaman MM. Physical activity levels and associated socio-demographic factors in Bangladeshi adults: a crosssectional study. BMC Public Health. 2017;17(59):1-8.

4- Atkinson K, Lowe S, Moore S. Human development, occupational structure and physical inactivity among 47 lowand middle income countries. Prev Med Repor. 2016;3(1):40-45.

5- Lee IM, Shiroma EJ, Lobelo F, Puska P, Blair SN, Katzmarzyk PT et al. Impact of Physical Inactivity on the World's Major Non-Communicable Diseases. Lancet. 2012;21:219-229.

6- World Health Organization. 2008-2013 Action plan for the global strategy for the prevention and control of noncommunicable diseases [Internet]. Geneva: World Health Organization; 2009.

7- WHO. Global recommendations on physical activity for health. World Health Organization. 2010. Geneva, Switzerland.

8- Bueno, DR Marucci MFN, Codgno JM, Roediger MA. Os custos da inatividade física no mundo: estudo de revisão. Ciência \& Saúde Coletiva. 2016;21(4):1001-1010.

9- Ranasinghe C, Sigera C, Ranasinghe P, Jayawardena R, Ranasinghe ACR, Hills AP, et al. Physical inactivity among physiotherapy undergraduates: exploring the knowledgepractice gap. BMC Sports Sci Med Rehabil. 2016; 8(39):1-9

10- Souza IL, Francisco PMSB, Lima MG, Barros MBA. Nível de inatividade física em diferentes domínios e fatores associados em adultos: Inquérito de Saúde no Município de Campinas (ISACamp, 2008/2009), São Paulo,
Brasil. Epidemiol. Serv. Saúde. 2014;23(4):623-634.

11- Warburton DER, Charlesworth S, Ivey A, Nettefolf L, Bredin SSD. A systematic review of the evidence for Canada's Physical Activity Guidelines for Adults. Int J Beh Nut Phys. Activ. 2010;7(39):1-220.

12- Gonçalves S, Hardt RJ, Silva AS, Haas P. Hypertension and physical activity importance. Estud. Biol. 2007;29(67):205-213.

13- Freitas Jr IF. Medidas: Estatura, Peso, Comprimento dos segmentos. In: Freitas Jr IF. Padronização de Técnicas Antropométricas. Presidente Prudente, SP: Cult Acad: 2009;23-5.

14- Andersson DP, Wahrenberg $H$, Toft E, V Qvisth, Lofgren P, Hertel K, Leijonhufvud BM, Thorell A, Naslund E, Arner P. Waist circumference to assess reversal of insulin resistance following weight reduction after bariatric surgery: cohort and cross-sectional studies. Int. J. Obes. 2013;1-6: doi:10.1038/ijo.2013.88.

15- Taylor RW, Jones IE, Williams SM, Goulding A. Evaluation of waist circumference, waist-to-hip ratio, and the conicity index as screening tools for high trunk fat mass, as measured by dual-energy X-ray absorptiometry, in children aged 3-19 y. Am J Clin Nutr. 2000;72(1):490-95.

16- Weber MA, Schiffrin EL, White WB, Mann S, Lindholm LH, Kenerson JG, Flack JM, Pharm BLC. Clinical Practice Guidelines for the Management of Hypertension in the Community. J Clin Hypertens. 2014;16(1):14-26.

17- Associação Brasileira de Empresas de Pesquisa. Critério de Classificação Econômica Brasil. Disponível em: www.abep.org Acessado em 24 de Maio de 2017.

18- Oliveira-Campos M, Maciel MG, Netos JF. Atividade física insuficiente: fatores associados e qualidade de vida. Rev Bras Ativ Fis Saúde. 2012; 17(6): 562-572.

19- Martini, FAN, Borges MB, Guedes DP. Hábito alimentar e síndrome metabólica em uma amostra de adultos brasileiros. Arch Latinoam Nutr. 2014;64(3):161-173.

20- Silva GAG, Fonsêca JDM, Souza IDT, Bezerra LAP, Lopes JM, Magnani KL. Nível de atividade física e aptidão cardiorrespiratória em escolares com sobrepeso/obesidade. Cons Saúde. 2015;14(2):263-269.

21- Torquato ED, Gerage AM, Meurer ST, Borges RA, Silva MC, Benedetti TRB. Comparação do nível de atividade física medido por acelerômetro e questionário IPAQ em idosos. Rev Bras Ativ Fís Saúde. 2016;21(2):144-153.

22- ASouza MM, Rocha SV, Santos CA, Vasconcelos LRC, Pinto LLT, Santos CES. Prevalência e fatores associados à inatividade física geral e no lazer em idosos residentes em áreas rurais. Arq de Cien do Esp. 2013;1(2):1-8.

23- BSouza CA, César CLG, Barros MBA, Carandina L, Goldbaum M, Marchioni DML, Fisberg RM. Prevalência de atividade física no lazer e fatores associados: estudo de base populacional em São Paulo, Brasil, 2008-2009. Cad. Saúde Pública, Rio de Janeiro. 2013;29(2):270-282.

24- Zanchetta LM, Barros MBA, César CLG, Carandina L, Goldbaum M, Alves MCGP. Inatividade física e fatores associados em adultos, São Paulo, Brasil. Rev Bras Epidemiol. 2010; 13(3):387-399.

25- Malta CD, Bernal RTI, Nunes ML, Oliveira MM, Iser BPM, Andrade SSCA, et al. Prevalência de fatores de risco e proteção para doenças crônicas não transmissíveis em adultos: estudo transversal, Brasil 2012. Epidemiol. Serv. Saúde. 2014;23(4):609-622.

26- Campanha-Versiani L, Silveira ECBR, Pimenta MC, Alvarenga SG, Parentoni NA, Ribeiro-Samora GA, et al. Influência da circunferência abdominal sobre o desempenho funcional de idosas. Fisioter Pesqui. 2010;17(4):317-21.

27- Sisson SB, Camhi SM, Church TS, Martin CK, Tudor-Locke C, Bouchard $C$, et al. Leisure time sedentary behavior, occupational/domestic physical activity, and metabolic syndrome in U.S. men and women. Metabolic Syndrome and Related Disorders. 2009;7(6):529-536.

28- Oliveira LPM, Assis AM, Silva MC, Santana MLP, Santos NSS, Pinheiro SMC, et al. Fatores associados a excesso de peso e concentração de gordura abdominal em adultos na cidade de Salvador, Bahia, Brasil. Cad Saúde Pública. 2009;25(3):570-82.

29- Elhakeem A, Hardy R, Bann D, Caleyachetty R, Cosco TD, Hayhoe RPG, et al. Intergenerational social mobility and leisure-time physical activity in adulthood: a systematic review. Epidemiol Community Health. 2016;0:1-8. 
30- Freire RS, Lélis FL, Filho JAF, Nepomuceno MA, Silveira MF. Prática regular de atividade física: estudo de base populacional no norte de Minas Gerais, Brasil. Rev Bras Med Esporte. 2014;20(5):345-349.

31- Piirtola M, Kaprio J, Kujala UM, Heikkilä K, Koskenvuo M, Svedberg P, et al. Association between education and future leisure-time physical inactivity: a study of Finnish twins over a 35-year follow-up. BMC Public Health. 2016;16(720):1-11.

32- Del-Duca GF, Nahas MV, Garcia LMT, Peres MA. Como gênero e escolaridade interagem nos padrões de inatividade física em diferentes domínios em adultos? Rev Bras Educ Fís Esporte. $2015 ; 29(4): 653-661$.
33- Turi BC, Codogno JS, Fernandes RA, Monteiro HL. Atividade física, obesidade abdominal e compra de medicamentos em adultos: estudo transversal retrospectivo com usuários da atenção básica de saúde. Rev Educ Fís/UEM. 2015;26(4):573-581.

34- Vilela APM, Coelho MP, Partelli ANM, Schmildt ER, Velten APC, Santos LGB, et al. Benefícios da atividade física no envelhecimento. Rev Guara. 2015;3:17-25.

35- Hegde SM. Solomon SD. Influence of Physical Activity on Hypertension and Cardiac Structure and Function. Curr Hypertens Rep. $2015 ; 17(10): 1-13$. 